\title{
Factors Affecting the Performance of Single-Chamber Soil Microbial Fuel Cells for Power Generation*1
}

\author{
DENG Huan ${ }^{1,2,3}$, WU Yi-Cheng ${ }^{1}$, ZHANG Fan ${ }^{1}$, HUANG Zong-Chuan ${ }^{1}$, CHEN Zheng ${ }^{2}$, XU Hui-Juan ${ }^{1}$ and \\ ZHAO Feng ${ }^{1, * 2}$ \\ ${ }^{1}$ Key Laboratory of Urban Environment and Health, Institute of Urban Environment, Chinese Academy of Sciences, Xiamen 361021 \\ (China) \\ ${ }^{2}$ Research Center for Eco-Environmental Sciences, Chinese Academy of Sciences, Beijing 100085 (China) \\ ${ }^{3}$ Department of Environmental Science and Engineering, Nanjing Normal University, Nanjing 210046 (China)
}

(Received July 5, 2013; revised March 17, 2014)

\begin{abstract}
There is limited information about the factors that affect the power generation of single-chamber microbial fuel cells (MFCs) using soil organic matter as a fuel source. We examined the effect of soil and water depths, and temperature on the performance of soil MFCs with anode being embedded in the flooded soil and cathode in the overlaying water. Results showed that the MFC with 5 $\mathrm{cm}$ deep soil and $3 \mathrm{~cm}$ overlaying water exhibited the highest open circuit voltage of $562 \mathrm{mV}$ and a power density of $0.72 \mathrm{~mW} \mathrm{~m}^{-2}$. The ohmic resistance increased with more soil and water. The polarization resistance of cathode increased with more soil while that of anode increased with more water. During the $30 \mathrm{~d}$ operation, the cell voltage positively correlated with temperature and reached a maximum of $162 \mathrm{mV}$ with a $500 \Omega$ external load. After the operation, the bacterial $16 \mathrm{~S}$ rRNA gene from the soil and anode was sequenced. The bacteria in the soil were more diverse than those adhere to the anode where the bacteria were mainly affiliated to Escherichia coli and Deltaproteobacteria. In summary, the two bacterial groups may generate electricity and the electrical properties were affected by temperature and the depth of soil and water.
\end{abstract}

Key Words: electrogenic bacteria, impedance, soil depth, soil organic matter, voltage

Citation: Deng, H., Wu, Y. C., Zhang, F., Huang, Z. C., Chen, Z., Xu, H. J. and Zhao, F. 2014. Factors affecting the performance of single-chamber soil microbial fuel cells for power generation. Pedosphere. 24(3): 330-338.

\section{INTRODUCTION}

Microbial fuel cells (MFCs) are devices that convert chemical energy directly into electricity. In an MFC, electrogenic bacteria degrade organic compounds under anaerobic condition and transfer electrons to anode. The electrons then flow through a conducting wire to cathode where the electron acceptors are reduced. The electrical current can be generated during the process. Materials with a large population of microorganisms and high content of organic matter have been used to generate power in MFCs, including marine sediment (Bond et al., 2002; Scott et al., 2008), sewage sludge (Zhang et al., 2012), garden compost (Parot et al., 2008), industrial/domestic wastewater (Rabaey and Verstraete, 2005) and animal waste (Yokoyama et al., 2006). Soil generally has a bacterial population of approximately $10^{9}$ cells $^{-1}$ (Whitman et al., 1998) and organic matter content of within 100 $\mathrm{mg} \mathrm{g}^{-1}$ (Bot and Benites, 2005), in spite of the variation between different soil types, e.g., in organic soil, the abundance of bacteria and organic matter can be much higher (Troeh and Thompson, 2005). The presence of bacteria and organic matter endows soil with the potential to be a vast resource of electrical energy.

Studies on soil MFCs exhibited various directions. Ishii et al. (2008a) found that methane emission from soil, which was filled in the anode chamber, was suppressed after running an MFC. The reason could be that the soil organic carbon was reduced to generate electrical power rather than methane. Another study showed that by running two chambered MFCs for $10 \mathrm{~d}$ with phenol contaminated soil in the anode chamber, $90 \%$ of phenol was removed from soil, compared with $13 \%$ in non-MFC control (Huang et al., 2011). Power generation was studied by inoculating rice paddy field

\footnotetext{
${ }^{* 1}$ Supported by the Main Direction Program of Knowledge Innovation of Chinese Academy of Sciences (No. KZCXZ-EW-402), the Hundred Talents Program of Chinese Academy of Sciences, the International S\&T Cooperation Program of China (No. 2011DFB91710), and the China Postdoctoral Science Foundation (Nos. 2011M500410 and 2012T50142).

*2 Corresponding author. E-mail: fzhao@iue.ac.cn.
} 
soil with cellulose as the energy resource in a twochamber MFC (Ishii et al., 2008b). However, soil MFC without the carbon addition may generate power by using its own organic matter as a fuel. Moreover, the cost of a single-chamber MFC is much lower than that of a two-chamber one. To keep $\mathrm{O}_{2}$ away from anode, single-chamber MFCs such as sediment-MFCs need a thick layer of soil or sediment, leading to a high internal resistance (Deng et al., 2012), thus the performance of single-chamber soil MFCs deserves studies. In addition, several factors were reported to have a major impact on the performance of MFCs. Internal resistance of MFCs increased with distance between electrodes (Jang et al., 2004); dissolved oxygen impaired the anaerobic conditions at anode and decreased power output (Kim et al., 2007); temperature was a major factor that seriously affected microbial activity and thus the electrogenic activity (Min et al., 2008). As a result, a study on the performance and the influencing factors of soil MFCs may help improve the efficiency of power output and soil remediation.

Electrogenic bacteria enrich on anode during the generation of current. Their composition differs between inoculums, although Geobacter and many other Deltaproteobacteria are well-known electrogenic bacteria and are often detected in anode biofilms (Franks et al., 2010; Logan, 2009). The sequencing method based on 16S rRNA gene was intensively used to understand the presence of electrogenic bacteria. Liu et al. (2011) found that Betaproteobacteria, Acetoanaerobium noterae and Chlorobium sp. dominated the anode biofilm when MFCs were fed with domestic wastewater. Ishii et al. (2008b) found that Clostridiales, Chloroflexi, Rhizobiales and Methanobacterium dominated the anode biofilm in MFCs inoculated with rice field soil and fed cellulose as fuels. Kaku et al. (2008) operated plant-MFCs in which soil organic carbon and root exudates served as energy resources, and found that Natronocella acetinitrilica, Beijerinckiaceae bacterium and Rhizobiales bacterium were dominant on anode. However, the fed cellulose or rhizosphere effects (Moorhead and Reddy, 1988) are selective for specific bacteria in soil. For MFCs using soil organic carbon as an energy resource, understanding the dominant bacteria in anode biofilm could help improve the performance of this kind of MFCs by optimizing the living conditions for these bacteria.

In this study, we hypothesized that the performance including cell voltage, power output and internal resistance were affected by electrode distance and temperature. To testify the hypothesis, MFCs were set up with a series of soil and water depths, and correla- tions between temperature and cell voltage were studied. Bacteria from soil and from anode were cloned and sequenced based on $16 \mathrm{~S}$ rRNA gene. The aims of this study were to understand i) the effect of soil and water depths, and temperature on the performance of soil MFCs; and ii) the electrogenic bacteria from soil.

\section{MATERIALS AND METHODS}

\section{Soil sampling}

Soil was collected in Jimei District, Xiamen City, China $\left(118^{\circ} 02^{\prime} \mathrm{N}, 24^{\circ} 37^{\prime} \mathrm{E}\right)$. The climate is subtropical and wet with a mean annual precipitation of 1200 $\mathrm{mm}$ and mean annual temperature of $21^{\circ} \mathrm{C}$. Soil sampling was carried out in October 2011. Soil was collected from an arid farmland at a depth of $0-20 \mathrm{~cm}$. After sampling, soil was gently separated by hand and passed through a $2 \mathrm{~mm}$ mesh.

\section{Soil chemical analysis}

After thorough mixing, a part of the soil was airdried for physiochemical analysis. Soil texture was determined using the pipette method (Gee and Bauder, 1986). Soil organic matter was measured using the $\mathrm{K}_{2} \mathrm{Cr}_{2} \mathrm{O}_{7}$ method (Sims and Haby, 1971). $\mathrm{NO}_{3}^{-}$and $\mathrm{NH}_{4}^{+}$were measured using ion chromatography (Mou et al., 1993). Soil pH was measured at a soil-water ratio of 1:2.5 (w:v). The soil physiochemical properties were as follows: texture, clay loam; organic matter, 27 $\mathrm{mg} \mathrm{kg}{ }^{-1} ; \mathrm{NO}_{3}^{-}, 50.2 \mathrm{mg} \mathrm{kg}{ }^{-1} ; \mathrm{NH}_{4}^{+}, 2.9 \mathrm{mg} \mathrm{kg}{ }^{-1}$; and $\mathrm{pH}, 6.5$.

\section{MFC set-up}

Six MFC reactors were constructed in Oroglas each with a dimension of $50 \mathrm{~cm} \times 30 \mathrm{~cm} \times 30 \mathrm{~cm}$ (length $\times$ width $\times$ height) (Fig. 1). In each reactor, the anode and cathode were carbon felt with an area of $0.150 \mathrm{~m}^{2}(50$ $\mathrm{cm} \times 30 \mathrm{~cm})$ and $0.045 \mathrm{~m}^{2}(30 \mathrm{~cm} \times 15 \mathrm{~cm})$, respectively. The thickness of the carbon felt was $0.5 \mathrm{~cm}$. The anode was positioned close to the bottom of the reactor and embedded with soil while the cathode was fixed at the overlaying water surface. The water was added gently to the soil and the MFCs were operated after the overlaying water was clear. The anode and cathode was connected with a $1000 \Omega$ external load using titanium wire. To study the relationship between electrical properties and depths of soil and overlaying water, five reactors were assigned to the following treatments: i) $3 \mathrm{~cm}$ soil with $3 \mathrm{~cm}$ water $(3 \mathrm{~S}+3 \mathrm{~W})$; ii) $5 \mathrm{~cm}$ soil with $3 \mathrm{~cm}$ water $(5 \mathrm{~S}+3 \mathrm{~W})$; iii) $7 \mathrm{~cm}$ soil with $3 \mathrm{~cm}$ water $(7 \mathrm{~S}+3 \mathrm{~W})$; iv) $5 \mathrm{~cm}$ soil with $6 \mathrm{~cm}$ water $(5 \mathrm{~S}+6 \mathrm{~W})$ and v) $5 \mathrm{~cm}$ soil with $9 \mathrm{~cm}$ water $(5 \mathrm{~S}+9 \mathrm{~W})$. Here the soil 
depth refers to the distance between anode surface and soil surface. The water depth refers to the distance between soil-water interface and water surface. To determine whether power was originated from microbial process or chemical process, an MFC reactor with soil sterilized by chloroform fumigation method (Wolf et al., 1989) was used as control treatment.

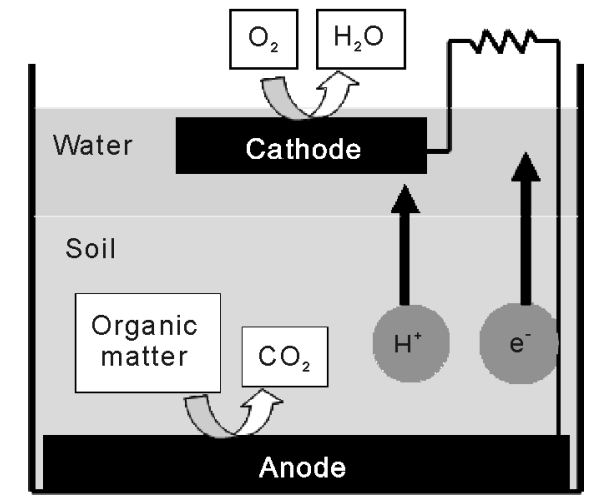

Fig. 1 Configuration of a microbial fuel cell using soil as energy resource.

\section{Electrical properties and dissolved oxygen}

Electrical properties of the MFCs treated with different depths of soil and water were determined after the voltage was stable at a constant temperature of $26{ }^{\circ} \mathrm{C}$. Maximum power was assessed via polarization curves, which were obtained by varying external resistance (open circuit, 30000, $10000,5000,2000$, $1000,500,200,100,50,20$ and $10 \Omega$ ). Each resistance was connected for $20 \mathrm{~min}$ and the voltage was recorded using a data acquisition module. Impedance spectroscopy was determined by using Autolab potentiostat (Eco Chemie BV, the Netherlands) at a sinusoidal excitation potential of $10 \mathrm{mV}$ and frequencies from $10^{-2}$ to $10^{5} \mathrm{~Hz}$. Impedance for the MFCs was determined in a two-electrode mode with anode serving as working electrode and cathode as counter electrode. The impedance spectroscopy was measured three times for each MFC. The concentration of dissolved oxygen at the anode surface and at water surface was determined at three points with an interval of $20 \mathrm{~cm}$ in each MFC by using a hand-held dissolved oxygen instrument (YSI Inc., Yellow Spring, USA).

\section{Dynamic performance of an $M F C$}

The MFC that generated the highest voltage was connected with a $500 \Omega$ external load and the voltage had been monitored for $30 \mathrm{~d}$ in a greenhouse. The voltage was recorded using a data acquisition module. The air temperature was recorded every 10 min using a
Vaisala MAWS301 automatic weather station (Vaisala Inc., Finland).

Three rhizon samplers (Rhizosphere Research Products, Wageningen, Netherlands) each with a filter (mesh size $0.45 \mu \mathrm{m}$ ) were embedded in the soil and above the anode at an interval of $20 \mathrm{~cm}$. Six milliliters of water was extracted in each rhizon sampler before and after the $30 \mathrm{~d}$ operation. The extract was subjected to $\mathrm{pH}$ and dissolved organic carbon (DOC) analyses with a pH meter and a TOC-V analyzer (Shimadzu Co., Japan), respectively.

\section{DNA extraction}

After the $30 \mathrm{~d}$ operation, a piece $(1.5 \mathrm{~cm} \times 1.5$ $\mathrm{cm}$ ) of the anode and $0.5 \mathrm{~g}$ soil above the anode was collected. The anode was rinsed with sterile deionized water before DNA extraction. The genomic DNA collected from the anode and soil was immediately extracted using the FastDNA ${ }^{\circledR}$ Spin kit for soil (Bio101 Inc., Carlsbad, USA) following the manufacturer's instructions. The purity and the quantity of the DNA were determined using a NanoDrop ND-1000 UV-Vis spectrophotometer (NanoDrop Technologies, Wilmington, USA) at 230, 260 and $280 \mathrm{~nm}$.

\section{Cloning, sequencing and phylogenetic analysis}

The DNA extracts from anode and soil served as the templates for polymerase chain reaction (PCR). The primer set $341 \mathrm{~F}\left(5^{\prime}\right.$-ACG GGG GGC CTA CGG GAG GCA GCA G-3') and 534R (5'-ATT ACC GCG GCT GCT GG-3') was used in the PCR amplification of 16S rRNA gene fragments (Muyzer et al., 1993). The $50 \mu \mathrm{L}$ reaction mixtures contained $1 \mu \mathrm{L}$ of template DNA, $1 \mu \mathrm{L}$ of each $1 \mu \mathrm{mol} \mathrm{L^{-1 }}$ primer, $5 \mu \mathrm{L}$ of 10 $\times$ buffer $\left(\mathrm{Mg}^{2+}\right.$ plus $), 4 \mu \mathrm{L}$ of $10 \mathrm{mmol} \mathrm{L}{ }^{-1} \mathrm{dNTPs}$ mixture (2.5 mmol L-1 of each) and 2.5 units of Taq DNA polymerase (Sangon Biotech Co., Ltd., Shanghai, China). Thermal cycling conditions were as follows: initial denaturation at $94{ }^{\circ} \mathrm{C}$ for $5 \mathrm{~min}$; 35 cycles consisting of denaturation at $94{ }^{\circ} \mathrm{C}$ for $1 \mathrm{~min}$, primer annealing at $52{ }^{\circ} \mathrm{C}$ for $40 \mathrm{~s}$, and elongation at $72{ }^{\circ} \mathrm{C}$ for $40 \mathrm{~s}$. The final elongation step was extended to 10 min. PCR products of the correct size were purified and then ligated to pMD18-T easy vector and transformed into Escherichia coli DH5 $\alpha$ competent cells. The bacteria were transferred into Luria-Bertani (LB) agar plates containing ampicillin, $\mathrm{X}-\mathrm{Gal}$ and isopropyl $\beta$-D-1-thiogalactopyranoside (IPTG). After incubation overnight at $37^{\circ} \mathrm{C}$, white colonies (putative positive clones) were picked as correct inserts. Two clone libraries each with 100 white clones were constructed for 
soil and anode, respectively. The clones with correct insert size were used for sequencing analyses (Invitrogen Co., Ltd., Shanghai, China). Vector sequences were removed using DNAStar Lasergene 7.1. The gene fragment sequences were subjected to taxonomic assignments by comparing the sequences with the nonredundant nucleotide database on BlastX http://ncbi. nlm.nih.gov/blast).

\section{Calculations and statistical analysis}

The power $(P, \mathrm{~W})$ and power density $\left(\mathrm{PD}, \mathrm{W} \mathrm{m}^{-2}\right)$ were calculated with the following formula:

$P=U^{2} / R$

$\mathrm{PD}=P / A$

where $U, R$ and $A$ is the voltage (V), external load $(\Omega)$ and anode area $\left(\mathrm{m}^{2}\right)$, respectively. The quantity of electrons, $Q$ (coulomb, C), produced from soil during the $30 \mathrm{~d}$ was evaluated with the following formula:

$Q=\sum_{n=1}^{4212} \frac{\left(I_{n}+I_{n+1}\right)}{2} \times 600$

where $I$ is the current (A), $n$ is the number of data that were recorded by a data acquisition module with a time interval of $600 \mathrm{~s}$. There are a total of 4212 data points.

The data of impedance spectra were fitted to an equivalent electrical circuit using the autolab impedance analysis software FRA 2 (Eco Chemie BV, the Netherlands). The total resistance $(R)$ is defined as:

$R=R_{\Omega}+R_{\mathrm{P}}^{\mathrm{a}}+R_{\mathrm{P}}^{\mathrm{c}}$

where $R_{\Omega}$ is ohmic resistance, $R_{\mathrm{P}}^{\mathrm{a}}$ and $R_{\mathrm{P}}^{\mathrm{c}}$ is the polarization resistance at anode and cathode, respectively (Manohar et al., 2008).

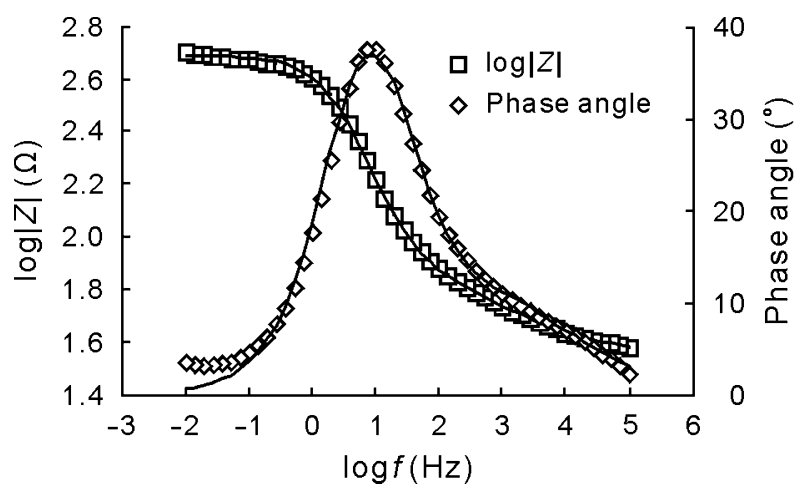

The significant correlation between cell voltage and air temperature was determined with the Pearson's correlation coefficient $(r)$. The significance in changes of DOC concentration and soil $\mathrm{pH}$ before and $30 \mathrm{~d}$ after the MFC operation was determined at the level of $P<0.05$ using independent-samples $t$-test. One-way ANOVA was used to determine the significant difference of dissolved oxygen between the MFCs at the level of $P<0.05$ using Duncan's test. All statistical tests were performed using SPSS software (version 14.0).

\section{RESULTS AND DISCUSSION}

\section{Impedance spectroscopy}

Equivalent circuit model that comprised two resistance-constant phase element (R-CPE) parallel circuits and an ohmic resistance was utilized to fit the impedance data (Figs. 2 and 3). Constant phase element (CPE) was employed in simulation because the electrode surface was rough and thus the dispersion effect was strong. $R_{\Omega}, R_{\mathrm{P}}^{\mathrm{a}}$ and $R_{\mathrm{P}}^{\mathrm{c}}$ explain major parts of internal resistance. The $R_{\mathrm{P}}^{\mathrm{c}}$ value was much higher than $R_{\mathrm{P}}^{\mathrm{a}}$ (Table $\mathrm{I}$ ), indicating that the oxidation of organic matter at the anode was much easier than the reduction of oxygen at the cathode. The use of modified cathode could accelerate the oxygen reduction rate and increase the power output (Zhao et al., 2005). There was a trend that $R_{\Omega}$ increased with the depths of soil and water or electrode distance. It was notable that $R_{\mathrm{P}}^{\mathrm{a}}$ sharply increased from 67.6 to $526.5 \Omega$ when the water depth increased from 3 to $9 \mathrm{~cm}$. The possible reason could be that carbon substrates were diluted with water and the anodic reaction rate was lowered. The $R_{\mathrm{P}}^{\mathrm{c}}$ value increased from 416.5 to $611.5 \Omega$ when soil depth increased from 3 to $7 \mathrm{~cm}$ at a constant $3 \mathrm{~cm}$ water depth. As shown in Fig. 4, the dissolved oxygen on the cathode significantly decreased with the increase of

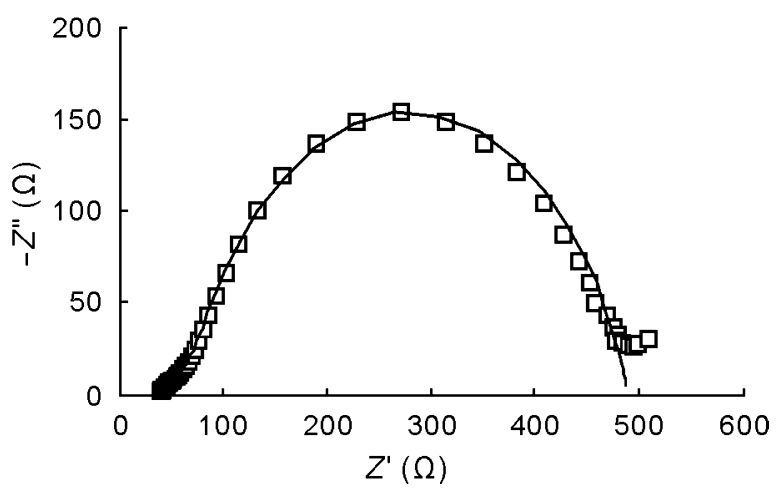

Fig. 2 Impedance spectra obtained in two electrode modes for a microbial fuel cell in the reactor treated with $3 \mathrm{~cm}$ soil and $3 \mathrm{~cm}$ overlaying water. $|Z|=$ impedance amplitude spectra; $Z^{\prime \prime}=$ imaginary impedance; $Z^{\prime}=$ real impedance; $f=$ the single frequency of a monochromatic signal (Bard and Faulkner 2000; Barsoukov and Macdonald, 2005). 


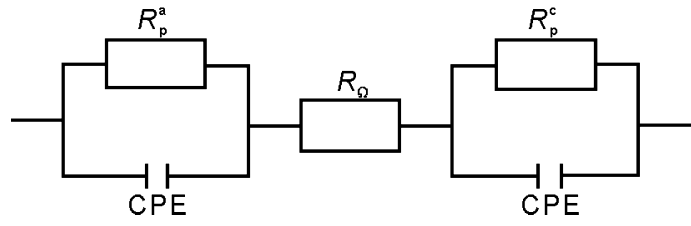

Fig. 3 Equivalent circuit for the analysis of impedance spectra data. $R_{\mathrm{P}}^{\mathrm{a}}=$ the polarization resistance of anode; $R_{\mathrm{P}}^{\mathrm{c}}=$ the polarization resistance of cathode; $R_{\Omega}=$ ohmic resistance; $\mathrm{CPE}=$ constant phase element.

\section{TABLE I}

Distance between anode and cathode and the total resistance $(R)$, which is the sum of ohmic resistance $\left(R_{\Omega}\right)$ and polarization resistance of anode $\left(R_{\mathrm{P}}^{\mathrm{a}}\right)$ and cathode $\left(R_{\mathrm{P}}^{\mathrm{c}}\right)$, in reactors treated with different depths of soil and water

\begin{tabular}{|c|c|c|c|c|c|}
\hline Treatment $^{\mathrm{a})}$ & Distance & $R_{\Omega}$ & $R_{\mathrm{P}}^{\mathrm{a}}$ & $R_{\mathrm{P}}^{\mathrm{c}}$ & $R$ \\
\hline & $\mathrm{cm}$ & \multicolumn{4}{|c|}{$\Omega$} \\
\hline $3 \mathrm{~S}+3 \mathrm{~W}$ & 6 & 36.0 & 37.3 & 416.5 & 489.8 \\
\hline $5 \mathrm{~S}+3 \mathrm{~W}$ & 8 & 43.6 & 67.6 & 362.1 & 473.3 \\
\hline $5 \mathrm{~S}+6 \mathrm{~W}$ & 11 & 42.0 & 194.1 & 319.0 & 555.1 \\
\hline $5 \mathrm{~S}+9 \mathrm{~W}$ & 14 & 45.0 & 526.5 & 402.2 & 973.7 \\
\hline $7 \mathrm{~S}+3 \mathrm{~W}$ & 10 & 53.6 & 52.9 & 611.5 & 718.0 \\
\hline
\end{tabular}

a) $3 \mathrm{~S}+3 \mathrm{~W}=3 \mathrm{~cm}$ soil with $3 \mathrm{~cm}$ overlaying water; $5 \mathrm{~S}+3 \mathrm{~W}=5$ $\mathrm{cm}$ soil with $3 \mathrm{~cm}$ overlaying water; $5 \mathrm{~S}+6 \mathrm{~W}=5 \mathrm{~cm}$ soil with 6 $\mathrm{cm}$ overlaying water; $5 \mathrm{~S}+9 \mathrm{~W}=5 \mathrm{~cm}$ soil with $9 \mathrm{~cm}$ overlaying water; $7 \mathrm{~S}+3 \mathrm{~W}=7 \mathrm{~cm}$ soil with $3 \mathrm{~cm}$ overlaying water.

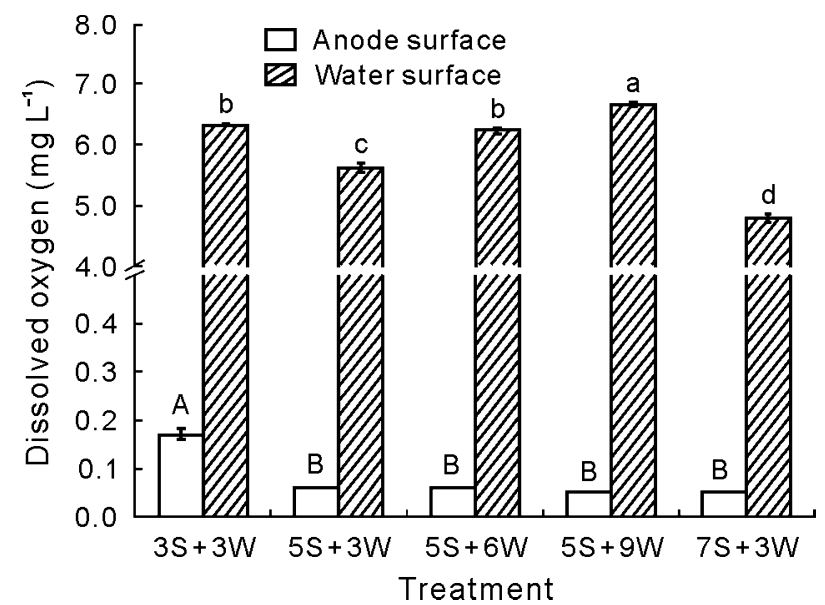

Fig. 4 Dissolved oxygen concentrations at the bottom of microbial fuel cell reactors and at water surface as affected by different depths of soil and water. $3 \mathrm{~S}+3 \mathrm{~W}=3 \mathrm{~cm}$ soil with $3 \mathrm{~cm}$ overlaying water; $5 \mathrm{~S}+3 \mathrm{~W}=5 \mathrm{~cm}$ soil with $3 \mathrm{~cm}$ overlaying water; $5 \mathrm{~S}+6 \mathrm{~W}=5 \mathrm{~cm}$ deep soil with $6 \mathrm{~cm}$ overlaying water; $5 \mathrm{~S}+9 \mathrm{~W}=$ $5 \mathrm{~cm}$ soil with $9 \mathrm{~cm}$ overlaying water; $7 \mathrm{~S}+3 \mathrm{~W}=7 \mathrm{~cm}$ soil with $3 \mathrm{~cm}$ overlaying water. Vertical bars represent standard errors of means. Bars with the same letter are not significantly different $(P<0.05, n=3)$ within anode surface (uppercase letter) or within water surface (lowercase letter) by Duncan's test.

soil depth. A possible reason was that the dissolved soil organic matter and oxygen demand increased in overlaying water with soil addition and thus the cathodic reaction rate declined. Since there was no replicate for impedance measurements, the significance of the impedance data was unknown.

\section{Open circuit voltage $(O C V)$ and power output}

The OCV showed a trend of $5 \mathrm{~S}+3 \mathrm{~W}(517 \mathrm{mV})>$ $7 \mathrm{~S}+3 \mathrm{~W}(451 \mathrm{mV})>3 \mathrm{~S}+3 \mathrm{~W}(350 \mathrm{mV})$, and $5 \mathrm{~S}+3 \mathrm{~W}$ $>5 \mathrm{~S}+6 \mathrm{~W}(506 \mathrm{mV})>5 \mathrm{~S}+9 \mathrm{~W}(470 \mathrm{mV})$ (Fig. 5$)$. The OCV in fumigated control was around $15 \mathrm{mV}$, indicating that the microorganisms played a crucial role in power generation. The power density of MFCs with different soil and water depths showed the same trend as OCV. The maximum power density and power of $5 \mathrm{~S}+3 \mathrm{~W}$ was $0.72 \mathrm{~mW} \mathrm{~m}^{-2}$ and $0.11 \mathrm{~W}$, respectively. The concentration of dissolved oxygen on the anode surface of $3 \mathrm{~S}+3 \mathrm{~W}$ was $0.17 \mathrm{mg} \mathrm{L}^{-1}$. It decreased to $0.06 \mathrm{mg} \mathrm{L}^{-1}$ in $5 \mathrm{~S}+3 \mathrm{~W}$ and $0.05 \mathrm{mg} \mathrm{L}^{-1}$ in $7 \mathrm{~S}+3 \mathrm{~W}$ (Fig. 4). A thicker layer of soil could more effectively limit oxygen diffusion to the anode surface, however, the internal resistance increased with more soil and water. The $5 \mathrm{~S}+3 \mathrm{~W}$ treatment effectively reduced oxygen content on the anode surface and meanwhile, had a relatively low resistance compared to other treatments (Table I), thus generating the highest voltage and
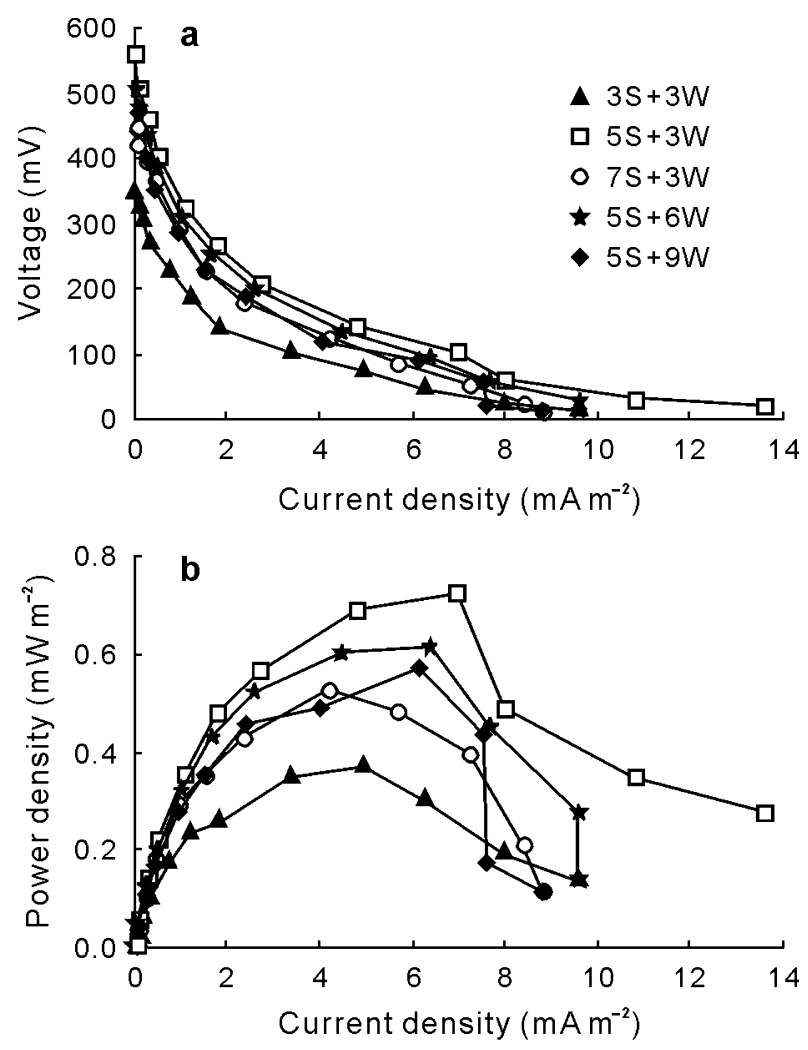

Fig. 5 Polarization curve (a) and power density (b) of microbial fuel cells in reactors as affected by different depths of soil and water. $3 \mathrm{~S}+3 \mathrm{~W}=3 \mathrm{~cm}$ soil with $3 \mathrm{~cm}$ overlaying water; $5 \mathrm{~S}+3 \mathrm{~W}$ $=5 \mathrm{~cm}$ soil with $3 \mathrm{~cm}$ overlaying water; $7 \mathrm{~S}+3 \mathrm{~W}=7 \mathrm{~cm}$ soil with $3 \mathrm{~cm}$ overlaying water; $5 \mathrm{~S}+6 \mathrm{~W}=5 \mathrm{~cm}$ soil with $6 \mathrm{~cm}$ overlaying water; $5 \mathrm{~S}+9 \mathrm{~W}=5 \mathrm{~cm}$ soil with $9 \mathrm{~cm}$ overlaying water. 
power. The power output could be further improved by adopting proper methods. An increase of the anode area could probably improve the columbic efficiency (Deng et al., 2012). The decomposition rate of organic matter can be accelerated at a temperature of over $30{ }^{\circ} \mathrm{C}$ (Kirschbaum, 1995) and the reduction rate of oxygen on cathode can be improved by more effective electrode materials (Zhao et al., 2005). Tender et al. (2008) used a sediment MFC that produced $30 \mathrm{~mW}$ to power a meteorological oceanographic buoy. Theoretically, the power can be possibly achieved with soil, which will function in a land ecosystem. The power can be harvested and stored for further needs. Moreover, the MFCs in our study were membrane free so that a large proportion of cost would be exempted in scaling up single-chamber MFCs (Deng et al., 2012).

\section{Dynamic performance of an $M F C$}

The voltage of the MFC with an external load of $500 \Omega$ and the air temperature was recorded during the $30 \mathrm{~d}$ operation (Fig. 6). The voltage increased from 45 $\mathrm{mV}$ to a maximum of $162 \mathrm{mV}$ during the first $9 \mathrm{~d}$ and then fluctuated around $100 \mathrm{mV}$. The voltage exhibited circadian oscillation that reached a maximum a little after noon (around 1:00-3:00 p.m.) and declined to
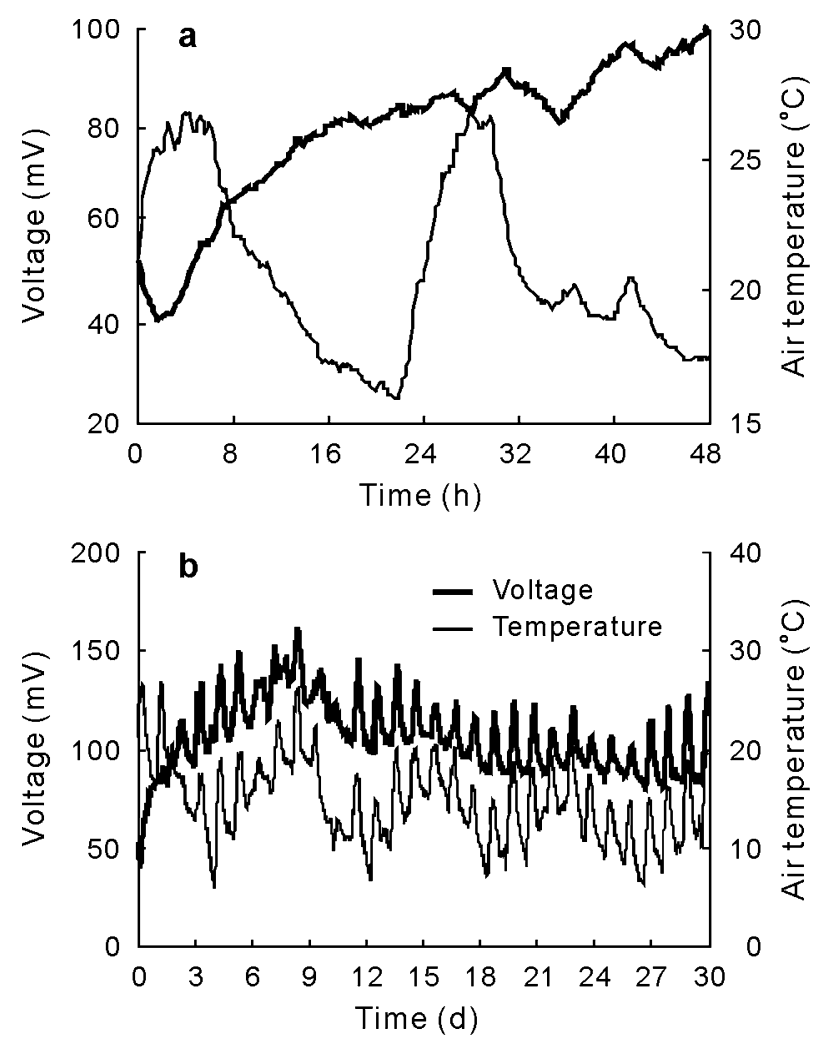

Fig. 6 Variation of the cell voltage under an external load of $500 \Omega$ in the reactor treated with $5 \mathrm{~cm}$ soil and $3 \mathrm{~cm}$ overlaying water and air temperature during the first $48 \mathrm{~h}$ (a) and $30 \mathrm{~d}$ (b) of operation. All data were recorded every $10 \mathrm{~min}$. the minimum at early morning (around 3:00-5:00 a.m.), except in the first $2 \mathrm{~d}$ when the cell voltage continuously increased. Correlation analysis showed that the voltage significantly correlated $(r=0.51$ $P<0.01)$ with the air temperature. This is possibly because the metabolic activities of electrogenic bacteria are temperature dependent.

The concentration of DOC averaged from three sampling points decreased from 63.4 to $55.2 \mathrm{mg} \mathrm{kg}^{-1}$ during the $30 \mathrm{~d}$. However, the difference did not reach the significant level $(P>0.05)$. The $\mathrm{pH}$ before operation $(\mathrm{pH} 6.41)$ was significantly higher $(P<0.05)$ than that after $30 \mathrm{~d}$ ( $\mathrm{pH} 6.24)$. A similar result was found by Parot et al. (2008), who reported that the $\mathrm{pH}$ value of compost decreased from 7.7 to 7.4 after current generation. It may be due to the $\mathrm{H}^{+}$accumulation during the fermentation of soil organic compounds.

According to Eq. 3, the soil totally generated a total of $541 \mathrm{C}$ or $5.62 \times 10^{-3} \mathrm{~mol}$ electrons in the $30 \mathrm{~d}$ operation. Theoretically, $1 \mathrm{~mol}$ of organic carbon generated 4 mol electrons when oxidized into $\mathrm{CO}_{2}$, and thus $1.41 \times 10^{-3} \mathrm{~mol}$ or $16.92 \mathrm{mg}$ organic carbon in soil was exhausted, taking up at most $2.7 \%$ of the $634 \mathrm{mg}$ DOC in the MFC with $10 \mathrm{~kg}$ soil.

\section{Bacterial community}

The 16S rRNA gene sequences from the soil covered a wider range of bacterial taxonomy than those from the anode (Tables II and III). Studies have shown that the microbial richness on the anode was lower than present in the surrounding media due to the enrichment of electrogenic bacteria (Holmes et al., 2004). In both clone libraries, sequences resembling $E$. coli were the most unexpectedly encountered, comprising $85 \%$ and $67 \%$ of sequences recovered from the anode and the soil, respectively. The $E$. coli being a major group was likely because the soil was from a farmland which was fertilized with manure. The enrichment of $E$. coli on the anode was due to extracellular electron transfer (Zhang et al., 2008; Qiao et al., 2009). The number of clones with $>97 \%$ similarity to Deltaproteobacteria was 5 from the anode and 2 from soil. Geobacter and other Deltaproteobacteria were known exoelectrogens (Phung et al., 2004). In addition, Bacteroidales (Rismani-Yazdi et al., 2007), Flavobacteria (Zhang et al., 2011) and Gemmatimonas cells were found on the anode or generate power in pure culture (da Rosa, 2010). A clone from the anode was affiliated to ironreducing bacterium, which was due to direct electron transfer to the anode. The presence of these bacterial groups on the anode indicates that soil microbial community may contain diverse electrogenic bacteria, tho- 
TABLE II

Sequence affinity of 99 clones representing major bacterial groups on the anode

\begin{tabular}{rlrl}
\hline No. of clones & Reference & Identity & Division \\
\hline 1 & Uncultured Alphaproteobacterium (JN409250) & $100 \%$ & Alphaproteobacteria \\
1 & Sphingomonas sp. (JQ660148) & $99 \%$ & \\
1 & Mesorhizobium sp. (JQ885930) & $98 \%$ & Gammaproteobacteria \\
5 & Escherichia coli (JQ912540) & $100 \%$ & \\
37 & Escherichia coli (JX096398) & $99 \%$ & Deltaproteobacteria \\
42 & Escherichia coli (JQ936087) & $99 \%$ & \\
1 & Uncultured Deltaproteobacterium (GU236077) & $95 \%$ & Chloroflexi \\
1 & Uncultured Deltaproteobacterium (EF521024) & $94 \%$ & Bacteroidetes \\
3 & Uncultured Geobacter sp. (HQ875546) & $98 \%$ & Gemmatimonadetes \\
2 & Uncultured Geobacter sp. (JN091629) & $97 \%$ & Unknown \\
1 & Uncultured Chloroflexi bacterium (HQ162740) & $97 \%$ & $100 \%$ \\
1 & Uncultured Bacteroidales bacterium (GU472709) & $98 \%$ & $97 \%$ \\
1 & Uncultured Flavobacteria bacterium (EU298065) & $99 \%$ & \\
\hline
\end{tabular}

TABLE III

Sequence affinity of 95 clones representing major bacterial groups in soil

\begin{tabular}{|c|c|c|c|}
\hline No. of clones & Reference & Identity & Division \\
\hline 2 & Uncultured Proteobacterium (HQ658851) & $98 \%$ & Proteobacteria \\
\hline 1 & Uncultured Alphaproteobacterium (JQ861384) & $99 \%$ & Alphaproteobacteria \\
\hline 1 & Chelatococcus sp. (AM412118) & $100 \%$ & \\
\hline 2 & Sphingomonas sp. (JQ660148) & $99 \%$ & \\
\hline 1 & Uncultured Betaproteobacterium (GU257706) & $98 \%$ & Betaproteobacteria \\
\hline 1 & Ralstonia sp. (GU966534) & $99 \%$ & \\
\hline 1 & Uncultured Gammaproteobacterium (GQ242901) & $94 \%$ & Gammaproteobacteria \\
\hline 25 & Escherichia coli (JX096398) & $100 \%$ & \\
\hline 6 & Escherichia coli (FJ997270) & $99 \%$ & \\
\hline 31 & Escherichia coli (JQ936087) & $99 \%$ & \\
\hline 2 & Escherichia coli (JQ912540) & $99 \%$ & \\
\hline 1 & Rhodanobacter sp. (FJ772029) & $100 \%$ & \\
\hline 1 & Uncultured Deltaproteobacterium (EF663513) & $96 \%$ & Deltaproteobacteria \\
\hline 1 & Uncultured Desulfuromonadales bacterium (JN692205) & $99 \%$ & \\
\hline 1 & Uncultured Geobacter sp. (FR774780) & $98 \%$ & \\
\hline 2 & Uncultured Actinobacterium (GU936357) & $100 \%$ & Actinobacteria \\
\hline 1 & Uncultured Actinobacterium (JQ400598) & $100 \%$ & \\
\hline 1 & Uncultured Actinobacterium (GU936366) & $97 \%$ & \\
\hline 1 & Streptomyces sp. (JF439427) & $99 \%$ & \\
\hline 1 & Nocardioides mesophilus (JQ899251) & $99 \%$ & \\
\hline 1 & Uncultured Nitrospirae bacterium (JN408986) & $100 \%$ & Nitrospirae \\
\hline 1 & Uncultured Acidobacteria bacterium (EF075172) & $99 \%$ & Acidobacteria \\
\hline 1 & Acidobacteriaceae bacterium (HQ995661) & $99 \%$ & \\
\hline 1 & Uncultured Acidobacteria bacterium (EF457486) & $100 \%$ & \\
\hline 1 & Acidobacteriaceae bacterium (AB245338) & $100 \%$ & \\
\hline 1 & Roseomonas sp. (HQ436503) & $100 \%$ & Chloroflexi \\
\hline 1 & Uncultured Chloroflexi bacterium (AB433048) & $96 \%$ & \\
\hline 1 & Uncultured Chloroflexi bacterium (JQ071694) & $99 \%$ & \\
\hline 1 & Virgibacillus sp. (GQ889491) & $96 \%$ & Firmicutes \\
\hline 1 & Bacillus sp. (JN202607) & $100 \%$ & \\
\hline 1 & Uncultured Bacillaceae bacterium (EU862155) & $100 \%$ & \\
\hline 1 & Uncultured Ktedobacteria bacterium (HQ674967) & $95 \%$ & Unknown \\
\hline
\end{tabular}

ugh the anaerobic condition, substrates and temperature in soil may not be the most favorable for electrogenic bacteria (Kim et al., 2012). Optimization of the growth condition for dominant electrogenic bacte- ria would improve the power output. In addition, fungal strains were found to generate current, such as Saccharomyces cerevisiae (Walker and Walker Jr., 2006) and Hansenula anomala (Prasad et al., 2007), which 
were frequently found in soil. In our study, soil pH at the anode decreased during the $30 \mathrm{~d}$ and there may be a shift from bacteria to fungi. Future study may investigate into the electrogenic fungi in soil and their contribution in power generation.

\section{CONCLUSIONS}

The power generation was largely influenced by factors of soil and water depths and temperature. There was a trade-off between internal impedance and soil depth or anaerobic condition of anode. In our study, the proper soil depth was $5 \mathrm{~cm}$, which may vary with soil types. E. coli and other electrogenic bacteria dominated the anode biofilm. It was suggested that the performance of MFCs, including power generation and the efficiency of soil remediation, could be improved under optimized living conditions for dominant electrogenic bacteria. Although the power output was low, soil microbial activities may be monitored by electrical signals, as illustrated by the results of positive relationship between temperature and cell voltage. Our results also suggest that the limitation for power generation mainly lies in the slow oxygen reduction rate at cathode. The application of high active electrode material together with sufficient anode area and optimal temperature could significantly improve the performance of soil MFCs.

\section{ACKNOWLEDGEMENT}

We thank Dr. M. Sievers from Nanjing Normal University, China for his kind help in improving the English writing.

\section{REFERENCES}

Bard, A. J. and Faulkner, L. R. (eds.). 2000. Electrochemical Methods: Fundamentals and Applications. 2nd Edition. John Wiley \& Sons, Inc., New York.

Barsoukov, E. and MacDonald, J. R. (eds.). 2005. Impedance Spectroscopy: Theory, Experiment, and Applications. 2nd Edition. John Wiley \& Sons, Inc., New York.

Bond, D. R., Holmes, D. E., Tender, L. M. and Lovley, D. R. 2002. Electrode-reducing microorganisms that harvest energy from marine sediments. Science. 295: 483-485.

Bot, A. and Benites, J. 2005. The Importance of Soil Organic Matter: Key to Drought-Resistant Soil and Sustained Food Production. FAO Soil Bulletin No. 80. FAO, Rome.

da Rosa, A. C. 2010. Diversity and function of the microbial community on anodes of sediment microbial fuel cells fueled by root exudates. Ph.D. Dissertation, Marburg University.

Deng, H., Chen, Z. and Zhao, F. 2012. Energy from plants and microorganisms: progress in plant-microbial fuel cells. ChemSusChem. 5: 1006-1011.

Franks, A. E., Malvankar, N. and Nevin, K. P. 2010. Bacterial biofilms: the powerhouse of a microbial fuel cell. Biofuels. 1: 589-604
Gee, G. W. and Bauder, J. W. 1986. Particle-size analysis. In Klute, A. (ed.) Methods of Soil Analysis. American Society of Agronomy, Soil Science Society of America, Madison. pp. 383-411.

Holmes, D. E., Bond, D. R., O'Neil, R. A., Reimers, C. E., Tender, L. R. and Lovley, D. R. 2004. Microbial communities associated with electrodes harvesting electricity from a variety of aquatic sediments. Microb. Ecol. 48: 178-190.

Huang, D. Y., Zhou, S. G., Chen, Q., Zhao, B., Yuan, Y. and Zhuang, L. 2011. Enhanced anaerobic degradation of organic pollutants in a soil microbial fuel cell. Chem. Eng. J. $\mathbf{1 7 2}$ 647-653.

Ishii, S., Hotta, Y. and Watanabe, K. 2008a. Methanogenesis versus electrogenesis: morphological and phylogenetic comparisons of microbial communities. Biosci. Biotechnol. Biochem. 72: 286-294.

Ishii, S., Shimoyama, T., Hotta, Y. and Watanabe, K. 2008b. Characterization of a filamentous biofilm community established in a cellulose-fed microbial fuel cell. BMC Microbiol. 8: $1-12$.

Jang, J. K., Pham, T. H., Chang, I. S., Kang, K. H., Moon, H., Cho, K. S. and Kim, B. H. 2004. Construction and operation of a novel mediator- and membrane-less microbial fuel cell. Process. Biochem. 39: 1007-1012.

Kaku, N., Yonezawa, N., Kodama, Y. and Watanabe, K. 2008. Plant/microbe cooperation for electricity generation in a rice paddy field. Appl. Microbiol. Biotechnol. 79: 43-49.

Kim, M. S., Cha, J. and Kim, D. H. 2012. Enhancing factors of electricity generation in a microbial fuel cell using Geobacter sulfurreducens. J. Microbiol. Biotechnol. 22: 1395-1400.

Kim, J. R., Cheng, S. A., Oh, S. E. and Logan, B. E. 2007. Power generation using different cation, anion, and ultrafiltration membranes in microbial fuel cells. Environ. Sci. Technol. 41: 1004-1009.

Kirschbaum, M. U. F. 1995. The temperature dependence of soil organic matter decomposition, and the effect of global warming on soil organic C storage. Soil Biol. Biochem. 27: 753-760.

Liu, G. L., Yates, M. D., Cheng, S. A., Call, D. F., Sun, D. and Logan, B. E. 2011. Examination of microbial fuel cell startup times with domestic wastewater and additional amendments. Bioresource Technol. 102: 7301-7306.

Logan, B. E. 2009. Exoelectrogenic bacteria that power microbial fuel cells. Nat. Rev. Microbiol. 7: 375-381.

Manohar, A. K., Bretschger, O., Nealson, K. H. and Mansfeld, F. 2008. The use of electrochemical impedance spectroscopy (EIS) in the evaluation of the electrochemical properties of a microbial fuel cell. Bioelectrochemistry. 72: 149-154.

Min, B., Román, Ó. B. and Angelidaki, I. 2008. Importance of temperature and anodic medium composition on microbial fuel cell (MFC) performance. Biotechnol. Lett. 30: 1213-1218.

Moorhead, K. K. and Reddy, K. R. 1988. Oxygen transport through selected aquatic macrophytes. J. Environ. Qual. 17: 138-142.

Mou, S. F., Wang, H. T. and Sun, Q. 1993. Simultaneous determination of the three main inorganic forms of nitrogen by ion chromatography. J. Chromatogr. A. 640: 161-165.

Muyzer, G., de Waal, E. C. and Uitterlinden, A. G. 1993. Profiling of complex microbial population by denaturing gradient gel electrophoresis analysis of polymerase chain reactionamplified genes coding for $16 \mathrm{~S}$ rRNA. Appl. Environ. Microbiol. 59: 695-700.

Parot, S., Délia, M. L. and Bergel, A. 2008. Forming electrochemically active biofilms from garden compost under chronoamperometry. Bioresource Technol. 99: 4809-4816. 
Phung, N. T., Lee, J., Kang, K. H., Chang, I. S., Gadd, G. M. and Kim, B. H. 2004. Analysis of microbial diversity in oligotrophic microbial fuel cells using $16 \mathrm{~S}$ rDNA sequences. FEMS Microbiol. Lett. 233: 77-82.

Prasad, D., Arun, S., Murugesan, M., Padmanaban, S., Satyanarayanan, R. S., Berchmans, S. and Yegnaraman, V. 2007. Direct electron transfer with yeast cells and construction of a mediator less microbial fuel cell. Biosens. Bioelectron. 22: 2604-2610.

Qiao, Y., Li, C. M., Lu, Z., Ling, H., Kang, A. and Chang, M. W. 2009. A time-course transcriptome analysis of Escherichia coli with direct electrochemistry behavior in microbial fuel cells. Chem. Commun. 41: 6183-6185.

Rabaey, K. and Verstraete, W. 2005. Microbial fuel cells: novel biotechnology for energy generation. Trends Biotechnol. 23: 291-298.

Rismani-Yazdi, H., Christy A. D., Dehority, B. A., Morrison, M., Yu, Z. and Tuovinen, O. H. 2007. Electricity generation from cellulose by rumen microorganisms in microbial fuel cells. Biotechnol. Bioeng. 97: 1398-1407.

Scott, K., Cotlarciuc, I., Hall, D., Lakeman, J. B. and Browning, D. 2008. Power from marine sediment fuel cells: the influence of anode material. J. Appl. Electrochem. 38: 1313-1319.

Sims, J. R. and Haby, V. A. 1971. Simplified colorimetric determination of soil organic matter. Soil Sci. 112: 137-141.

Tender, L. M., Gray, S. A., Groveman, E., Lowy, D. A., Kauffman, P., Melhado, J., Tyce, R. C., Flynn, D., Petrecca, R. and Dobarro, J. 2008. The first demonstration of a microbial fuel cell as a viable power supply: Powering a meteorological buoy. J. Power Sources. 179: 571-575.

Troeh, F. R. and Thompson, M. L. (ed.). 2005. Soils and Soil
Fertility, 6th Edition. Blackwell, Ames.

Walker, A. L. and Walker Jr., C. W. 2006. Biological fuel cell and an application as a reserve power source. J. Power Sources. 160: $123-129$.

Whitman, W. B., Coleman, D. C. and Wiebe, W. J. 1998. Prokaryotes: the unseen majority. P. Nat. Acad. Sci. USA. 95: 6578-6583.

Wolf, D. C., Dao, T. H., Scott, H. D. and Lavy, T. L. 1989. Influence of sterilization methods on selected soil microbiological physical, and chemical properties. J. Environ. Qual. 18: 3944.

Yokoyama, H., Ohmori, H., Ishida, M., Waki, M. and Tanaka, Y. 2006. Treatment of cow-waste slurry by a microbial fuel cell and the properties of the treated slurry as a liquid manure. Anim. Sci. J. 77: 634-638.

Zhang, T., Cui, C. Z., Chen, S. L., Yang, H. X. and Shen, P. 2008. The direct electrocatalysis of Escherichia coli through electroactivated excretion in microbial fuel cell. Electrochem. Commum. 10: 293-297.

Zhang, Y. F., Min, B., Huang, L. P. and Angelidaki, I. 2011. Electricity generation and microbial community response to substrate changes in microbial fuel cell. Bioresource Technol. 102: $1166-1173$.

Zhang, G., Zhao, Q., Jiao, Y., Wang, K., Lee, D. J. and Ren, N. 2012. Efficient electricity generation from sewage sludge using biocathode microbial fuel cell. Water Res. 46: 43-52.

Zhao, F., Harnisch, F., Schröder, U., Scholz, F., Bogdanoff, P. and Herrmann, I. 2005. Application of pyrolysed iron(II) phthalocyanine and CoTMPP based oxygen reduction catalysts as cathode materials in microbial fuel cells. Electrochem. Commun. 7: 1405-1410. 